\title{
The Diagnosis of Multiple Myeloma With Macroglossia and Edema Symptoms
}

\author{
Sonat Pınar Kara, ${ }^{1}$ Atakan Tekinalp,, ${ }^{2}$ Bülent Bilir, ${ }^{1}$ Hasan Değirmenci, ${ }^{3}$ \\ Okan Avcl, ${ }^{1}$ Meltem Öznur, ${ }^{4}$ Burhan Turgut ${ }^{2}$
}

\begin{abstract}
'Department of Internal Medicine, Namık Kemal University Faculty of Medicine, Tekirdağ, Turkey

${ }^{2}$ Department of Hematology, Namık Kemal University Faculty of Medicine, Tekirdağ, Turkey

${ }^{3}$ Department of Cardiology, Namık Kemal University Faculty of Medicine, Tekirdağ, Turkey

${ }^{4}$ Department of Pathology, Namık Kemal University Faculty of Medicine, Tekirdağ, Turkey
\end{abstract}

Submitted: 18.07.2016 Accepted: 26.12 .2016

Correspondence: Meltem Öznur Namık Kemal Üniversites

Tıp Fakültesi, Patoloji Anabilim Dalı, 59200 Tekirdağ, Turkey

E-mail:mltm.znr@hotmail.com

Keywords: Edema; heart failure; macroglossia; multiple myeloma.

\begin{abstract}
In this case, the importance of multiple myeloma in differential diagnosis of non-specific symptoms, such as macroglossia and significant pretibial edema, is highlighted. A 44-year-old male presented to the internal medicine outpatient clinic with complaints of ongoing and increasing enlargement of the tongue, difficulty in swallowing, and swelling of legs, all of which had been occurring for 6 months. In the CT scan, significant symmetrical enlargement of the tongue was detected. Making a pre-diagnosis of amyloidosis, a biopsy of the tongue was performed, but the results did not suggest amyloidosis. A rectal biopsy was therefore subsequently performed, and this time the results showed amyloid accumulation. Findings from the transthoracic echocardiography showed an ejection fraction of $48 \%$, contrast hypertrophy in the left ventricle, Grade 3 diastolic dysfunction, $15-19 \mathrm{ml}$ of pericardial fluid around the heart, and mild mitral failure. Taking into consideration the pathological and cardiologic findings, the patient was diagnosed with amyloidosis. Bearing in mind the possible relation between primary hematologic malignancy and amyloidosis, a bone marrow aspiration and a bone marrow biopsy were performed. From the results of the biopsy and aspiration of bone marrow, the patient was diagnosed with multiple myeloma and treatment plans were made accordingly. However, as the patient was in the process of undergoing treatment he died due to the development of cardiopulmonary failure.
\end{abstract}

\section{INTRODUCTION}

Amyloids are extracellular abnormal proteinaceous substances that accumulate in the tissues and organs, wherein they can lead to a variety of dysfunctions. For example, accumulation in the small intestine may cause malabsorption, accumulation in the kidney, may cause kidney failure, and accumulation in the heart may cause heart failure symptoms. Sudden death can occur in cases where normal tissues in the heart, kidney and gastrointestinal tract (GIT) are destroyed. Amyloidosis can be seen in different forms, such as primary, secondary, localized, multiple myeloma and heredofamilial.[. ${ }^{[]}$Amyloid deposits may be systemic or localized. Localized amyloidosis is caused by amyloid-in- duced tissue, whereas systemic amyloidosis is caused by precursor cells, where amyloid is synthesized and secreted. Accumulated fibrils are resistant to proteolytic enzymes. In secondary amyloidosis, serum amyloid-A (SAA) secreted from the liver due to inflammation accumulates in tissues and organs, such as the $\mathrm{Gl}$, heart, kidney, and thyroid. ${ }^{[2]}$

Primary amyloidosis (AL amyloidosis) associated with multiple myeloma (MM) can be either systemic or local. In $\mathrm{AL}$ amyloidosis, multiple myeloma clonal cells in the bone marrow produce amyloidogenic immunoglobulins. AL accumulation occurs in organs, such as the liver, heart, kidney and spleen. ${ }^{[2]}$ 

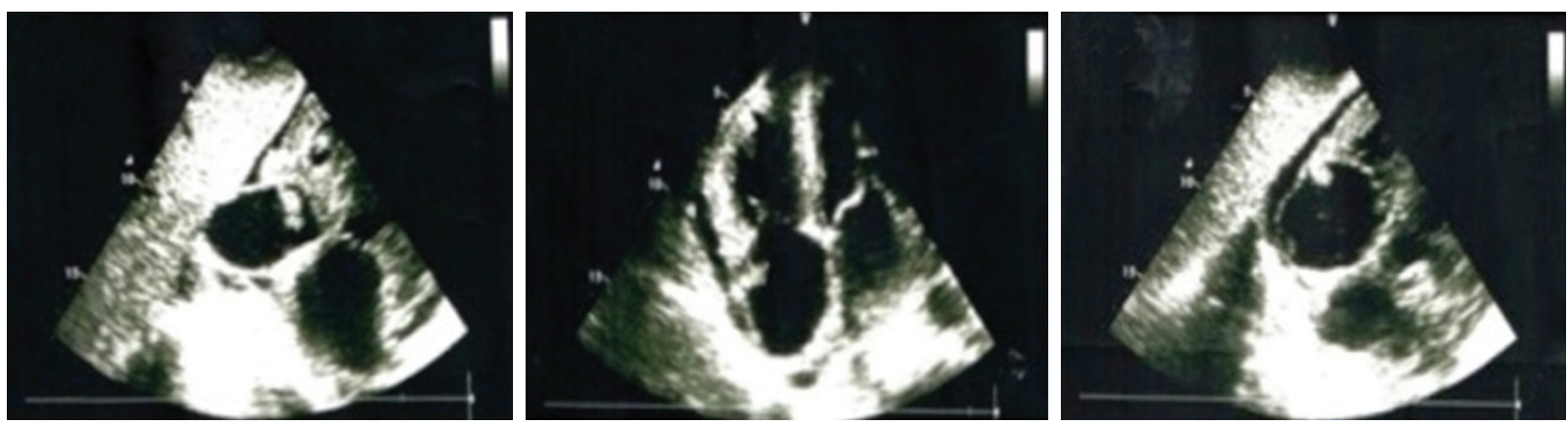

Figure 1. Transthoracic echocardiographic examination shows stage-3 diastolic function and pericardial fluid.

Localized amyloidosis is very rare, and is usually seen as secondary to systemic diseases. ${ }^{[2]}$ There are reports in the literature of cases of MM with amyloidosis and systemic disease. ${ }^{[3,4]}$ Here, we present a 44-year-old male with MM who had a diagnosis of macroglossia and edema.

\section{CASE REPORT}

A 44-year-old male patient presented to the Internal Medicine outpatient clinic with complaints of progressive enlargement of the tongue and struggles with swallowing, which had been occurring for 6 months. The patient also complained of swelling in his legs and weight loss of about $10 \mathrm{~kg}$. Patient was hospitalized in order to evaluate possible diseases associated with differential diagnosis for tongue enlargement.

On detailed physical examination, a decrease in respiratory sounds in the left hemithorax lower zone, bilateral Grade- 3 gonadal edema in the legs, and marked abdominal distention were detected. Laboratory results showed that all series were at normal limits, save for low levels of globulin (IgG: $362 \mathrm{mg} / \mathrm{dL}$, IgM: $16 \mathrm{mg} / \mathrm{dL}$, IgA: $48 \mathrm{mg} / \mathrm{dL}$ )
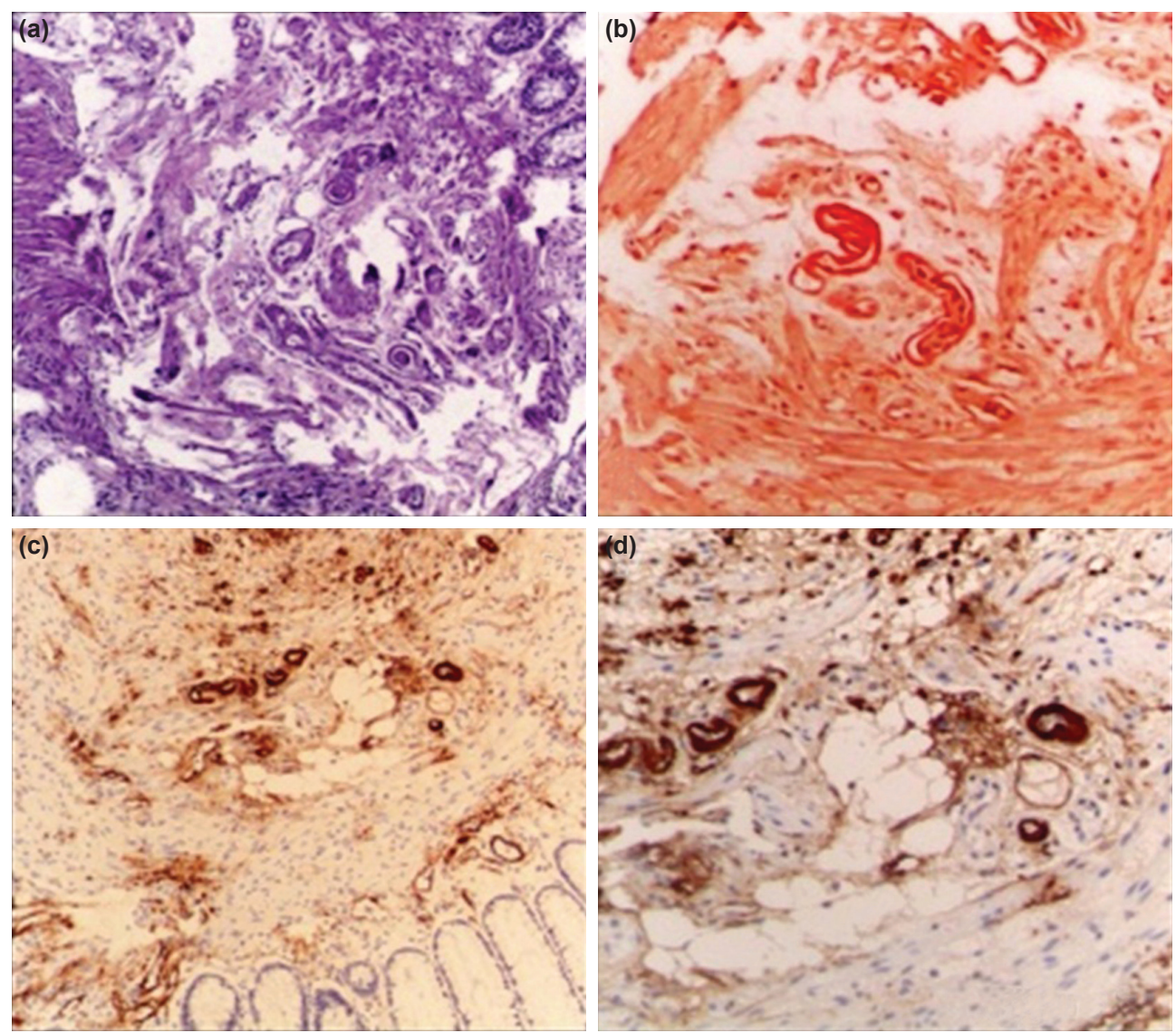

Figure 2. This picture, which is composed of four sections, has H\&E painted sections; (a) accumulation of homogenous pink matter in the vicinity of the vein wall, (b) congo red, (c, d) amyloid deposits were shown in amyloid AL staining with immunohistochemical methods. 
and a $24 \mathrm{~h}$ protein level of $1330 \mathrm{mg} / \mathrm{dL}$. On the neck computerized tomography (CT) examination, a symmetrical increase in the lingual size was observed. A tongue biopsy was performed after making a preliminary diagnosis of amyloidosis-related macroglossia. Hematoxylin-eosin $(\mathrm{H}$ \& E) stained sections were prepared from the tongue biopsy material, with the exception of the regular infiltration of squamous epithelium and mild inflammatory cells in the subepithelial area. Amyloid deposits were not detected in the Congo red dye applied on the material.

Transthoracic echocardiography showed $48 \%$ ejection fraction, concentric hypertrophy in left ventricle, Grade 3 diastolic dysfunction in the left ventricle, $15-19 \mathrm{~mm}$ of pericardial fluid around the heart and mild mitral regurgitation (Fig. I). Electrocardiographic examination revealed sinus rhythm, right branch block, low voltage and pseudoinfarction pattern in extremity leads. These cardiologic findings led us to make a preliminary diagnosis of cardiac amyloidosis.

A rectal biopsy was performed for the purpose of making a definitive diagnosis, since the findings from the tongue biopsy were not compatible with our preliminary diagnosis. In the H\&E stained sections prepared from the biopsy material of the rectum, an homogenous accumulation of pink color was observed around the vein wall. Amyloid accumulation was demonstrated in amyloid AL staining applied with Congo red and through the immunohistochemical analysis applied on the material (Figure 2a-d). Pathologic and cardiologic findings revealed amyloidosis in the patient. Bone marrow aspiration and a bone marrow biopsy were performed since the cause of amyloidosis was primary hematological malignancy. Bone marrow aspiration contained $15 \%$ plasma cell infiltration and flow cytometric examination revealed a malignant plasma cell population of $10.4 \%$. Atypical cell infiltration in plasmacytoid morphology was detected in $\mathrm{H}$ \& $\mathrm{E}$ sections prepared from bone marrow biopsy material. Atypical cells were found in CD38 (+), CDI38 (+), Kappa (+), and Lambda (-) in the immunohistochemical study. With all these findings, multiple myeloma was diagnosed and treatment was planned. In the process of undergoing treatment, the patient died due to the development of cardiopulmonary insufficiency. Informed consent was taken from the patient.

\section{DISCUSSION}

$M M$ is a plasma cell discoid with an unknown etiology. $M M$ is a hematologic malignancy characterized by hypercalcemia, osteolytic bone lesions, increased monoclonal protein in serum and/or urine, and renal insufficiency. The primary amyloidosis seen in MM may be systemic or local. MM patients usually present to the hospital because of bone fractures and accompanying pain associated with lytic bone lesions. With a pre-diagnosis of amyloidosis, a rectal biopsy was performed, with the finding showing $A L$ amyloidosis, with no symptoms or signs of MM disease. The patient received an MRI after bone marrow aspiration and biopsy results.

Laryngeal involvement in the head and neck region has been reported in localized storage, but tongue involvement has often been shown to be secondary to systemic diseases. ${ }^{[3]}$ Apart from amyloidosis, systemic diseases, such as malign tumors, vascular tongue and neck diseases, acromegaly and hypothyroidism, or vitamin BI 2 deficiency and folic acid deficiency, or metabolic diseases, such as amyloidosis, should also be considered in the differential diagnosis. ${ }^{[2]}$ Macroglossia is seen in $25 \%$ of patients with systemic amyloidosis. ${ }^{[6]}$ When lingual amyloidosis is detected, a complete blood count, liver function tests, renal function tests, echocardiography to investigate cardiac involvement, serum and urine tests to determine if there is the presence of "Bence Jones Proteins", and biopsies from rectum and abdominal wall fat are typically performed to investigate systemic amyloidosis. ${ }^{[3,5]}$

Cardiac involvement is most commonly seen in primary amyloidosis. Cardiac amyloidosis is observed in approximately $50 \%$ of patients with systemic amyloidosis and functions as the most significant source of mortality in patients with $\mathrm{AL}$ amyloidosis. ${ }^{[7]}$ In our case, we had diastolic cardiac insufficiency due to cardiac involvement and related symptoms.

Systemic amyloidosis has been described in 5-15\% of patients with $M M^{\left[{ }^{[8]}\right.}$ Because there are no laboratory parameters available for assessing amyloidosis in patients with $M M$, it is best to perform a biopsy of the lesions that are accessible and that look suspicious. ${ }^{\left[{ }^{9]}\right.}$

\section{Conclusion}

In this case study, it has been shown that from an initial diagnosis of $A L$ amyloidosis, although only rarely seen in patients with cardiac insufficiency symptoms, such as ede$\mathrm{ma}$, or in patients with macroglossia, an MM diagnosis can be reached.

Authorship contributions

Concept: S.P.K.; Design: S.P.K., M.Ö.; Data collection \&/ or processing: A.T., H.D.; Analysis and/or interpretation: O.A., B.B.; Literature search: S.P.K., M.Ö.; Writing: S.P.K., M.Ö.; Critical review: B.T.

Conflict of interest

None declared.

\section{REFERENCES}

1. Kyle RA, Bayrd ED. Amyloidosis: Review of 236 cases. Medicine 1975;54:271-99. [CrossRef]

2. Fahrner KS, Black CC, Gosselin BJ. Localizedamyloidosis of the- 
tongue: a review. Am J Otolaryngol 2004;25:186-9. [CrossRef]

3. Padfield GJ, Maclay JD. Macroglossia andcomplete heart block in a womanwith multiplemyeloma. QJM 2010;103:271-2. [CrossRef]

4. Brandstetter M, Matsuba Y, Knopf A. A tonguebiopsyledtothediagnosis. HNO 2012;60:443-5. [CrossRef]

5. Penner CR, Mülller S. Headandneckamyloidosis: a clinicopathologicstudy of 15 cases. Oral Oncology 2006:42:421-9. [CrossRef]

6. Mardinger O, Rotenberg L, Chaushu G, Taicher S. Surgicalmanagement of macroglossiaduetoprimaryamyloidosis. Int J Oral Maxillofac Surg 1999;28:129-31. [CrossRef]
7. Kristen AV, Perz JB, Schonland SO, Hegenbart U, Schnabel PA, Kristen JH, et al. Non-invasive predictors of survival in cardiac amyloidosis. Eur J Heart Fail 2007;9:617-24. [CrossRef]

8. Kumar V, Abbas AK, Fausto N, Aster JC. Diseases of theimmunesystem. In: Schmitt W, Gruliow R, editors. Robbins and Cotran Pathologic Basis of Disease. 8th ed. Philadelphia: Saunders Elsevier; 2010. pp. 249-55.

9. Vasudevan JA, Somanathan T, Patil SA, Kattoor J. Primarysystemic amyloidosis of tongue withchondroidmetaplasia. J Oral MaxillofacPathol 2013;17:266-8.

\section{Makroglossi ve Ödem Bulguları ile Multipl Miyelom Tanısı}

Bu olgu sunumunda makroglossi ve belirgin pretibial ödem gibi, non-spesifik semptomların ayırıcı tanısında multipl miyelomun da yer alabileceğinin önemi vurgulandı. Kırk dört yaşında erkek hasta, altı aydır devam eden ve giderek artan dilde büyüme, yutkunma zorluğu, bacaklarda şişlik şikayetiyle iç hastalıkları polikliniğine başvurdu. Boyun bilgisayarlı tomografi incelemesinde, dil boyutlarında simetrik belirgin artış gözlendi. Amioloidoza bağlı makroglossi ön tanısıyla dil biyopsisi gerçekleştirildi. Dil biyopsisi sonucu amiloidozla uyumlu bulguların saptanmaması üzerine rektal biyopsi yapıldı. Rektal biyopside amiloid birikimi gösterildi. Transtorasik ekokardiografide ejeksiyon fraksiyonu \%48, sol ventrikülde konsantrik hipertrofi, evre-3 diyastolik disfonksiyon, kalp çevresinde $15-19 \mathrm{~mm}$ perikardiyal sıvı ve hafif mitral yetersizliği tespit edildi. Patolojik ve kardiyolojik bulgular ışı̆ıında hastaya amiloidoz tanısı konuldu. Amiloidoz tanısının primer hematolojik maliginite ile ilişkilendirilebileceği düşünülerek kemik iliği aspirasyon ve biyopsisi yapıldı. Kemik iliği aspirasyon ve biyopsi sonucunda multipl miyelom tanısı konulan ve tedavisi planlanan hasta kardiyopulmoner yetersizlik nedeniyle hayatını kaybetti.

Anahtar Sözcükler: kalp yetersizliği; makroglossi; multipl miyelom; ödem. 